\title{
車椅子マラソンの運動負荷後の心機能への影響評価
}

\author{
正 員 吉原 宗三郎(大分県教育センター) \\ 正 員 西村 敏博 (大分大学) \\ 非会員 細川 博司 (大分医科大学) \\ 正 員 濱本 和彦 (東海大学) \\ 正 員 斎藤 正男 (東京電機大学)
}

\section{An evaluation of the influence on the cardiac function after excessive exercise is loaded at the wheelchair marathon}

\author{
Sozaburo Yoshihara, Member (Oita Prefectural Education Center) \\ Toshihiro Nishimura, Member(Oita University) \\ Hiroshi Hosokawa, Non Member(Oita Medical University) \\ Kazuhiko Hamamoto, Member(Tokai University) \\ Masao Saito, Member(Tokyo Denki University)
}

\begin{abstract}
In this paper, we examined the safety during the wheelchair marathon. By monitoring the cardiac function and the metabolic function at the same time through the blood and biochemical labo-data analysis, electrocardiogram, Holter's electrocardiogram and RR time series analysis and echocardiogram in the subjects at the wheelchair marathon. Heart rate increased significantly from $66.0 \pm 12.6$ to $99.0 \pm 10.8$ beat/min. Systolic blood pressure increased significantly from $117.7 \pm 18.6$ to $143 \pm 12.6 \mathrm{~mm} \mathrm{Hg}$. Diastolic blood pressure decreased significantly from $70.0 \pm 10.4$ to $45.0 \pm 8.8 \mathrm{mmHg}$. No changes in left ventricular function and size on the echocardiogram. The findings of dehydration were not recognized after the race. The increase in plasma TAT complex concentrations was significantly greater from $2.2 \pm 0.4$ to $4.0 \pm$ $0.6 \mathrm{ng} / \mathrm{ml}$. WBC was significantly increased from $7.0 \pm 1.9$ to $13.3 \pm 5.6 \times 10^{3} / \mu 1$. No other measurement items significantly changed after the race. The findings of arrhythmias. (supraventricular premature count, ventricular premature count, or other block etc.) were not significantly recognized during the race. In this paper, it is possible that these subjects who have hardly atherosclerosis, if they enter the race after full training and with supplying water, do safely without the bad influence to the heart. But old age athlete with atherosclerosis should be done full medical check before the race in the future.
\end{abstract}

キーワード: 心機能動態, 車椅子マラソン, 身体障害老,心電図RR間隔時系列,心エコー図, 血液生化学検查

\section{1. まえがき}

本研究は，身体障害者による車椅子マラソン競技前 後および競技中の心機能動態を生理学的および生化 学的に把握し, 身体障害者間で近年急速な広がりをみ せている連動競技に対寸る保健医療福祉の連携の重 要性を訴える医学的評価を行引ものである。

身体障害者とくに下肢の不自由な者が残された機能 である上肢を余すところなく駆使しておこなう車椅子マ
ラソンでの心機能と凝固線溶系を両面から評価した研 究はほとんどなく, 医療行政上も今後とも事故なくここの 種の行事が普及するように配慮する上でも貴重な医学 的根拠となる。近年, 身体障害者の中高年化にともな い, 特に脊䯣損傷患者にも，競技中の心血管采の事 故が章慮される現況において, 日頃から充分鍛鍊して いるとはいえ, 競技前後の的確なへルスチエックおよび 救急医療体制を通して, 安全で楽しい健康づくり運動 としての身体障害者のスポーツの発展をめざすよう，そ 
の普及発展をはかるものである。

近年、競技数、競技人口とも増加しつつある身体障 害者による車椅子マラソンは、下肢の不自由な状態で、 上肢を主体に上半身を連続して、しか吼長時間運動し て、そのスピードを競う過酷な耐久レースであるため、 生体の代謝や循環動態などに種々の影響を及ぼし、 脱水、突然死などの危険性もあり、救急医療を初めと する周囲の保健医療および福祉行政とも密接な関係を 有する。しかし安全性の検討は必ずしも十分とは言え ず、特に突然死の原因となり得る心機能の変化を観察 した報告は少ない1)。今回, 車椅子マラソン大会の参加 者を対象にして競技前後の心電図，心エコー図，血液 生化学検查を行い，さらに競技中のホル夕ー心電図よ VRR間隔時系列の解析を用い、競技前後および競技 中の心機能および代謝機能を同時に評価し，競技の 安全性について検討寻る。

\section{2. 測定方法}

\section{1 対象及び方法}

対象は、第15回大分国際車椅子マラソン大会参加者

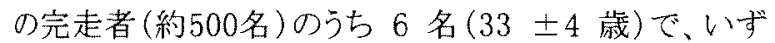
れも男性の常連の車椅子マラソンランナ一である。心 電図, 心エコ一図, 血液生化学検査の各測定項目に つては, 競技前日夕刻とゴール後15分以内の計2回 行い,その変化を比較検討する。ホルター心電図につ いては競技中連続記録を行った。なお、対象者に対し ては㭘查の目的および安全性について十分説明した 後、文書による同意を得ている。

\section{2 測定項目}

\section{(1) 心電㘝}

心電図の標準12誘導について3分間記録し、不整脈 の出現およびST変化を観察するとともに，P波高，P波 幅, $\mathrm{PQ}$ 時間, QT時間, R-R間隔, R波高を求める。 単極胸部誘導加は, T波高の変化を観察する ${ }^{6 !}$ 。

(2)心エコー四

心エコ一図は，2万向心断層法をもとにした B モー ドおよびMモードで記録し，心室中隔および左室後壁 エコー図の左室収寉期および抬張期径より Pombo 法 を用いて、それぞれの容積老計算し、これから心拍出 量, 駆出率を求める。また、僧帽弁前尖エコ一図上り diastolic descent rate (DDR)を, また大動脈弁エコー 図より, preejection period / left ventricular ejection time (PEP/LVET), 右室径, 左房径求める。また平 均血圧を心拍数で除して末梢血管抵抗とした。統計学 的処理は、Student $の$ pairedt検定を用い, $p<0.05$
をもって有意とした。

(3) 血液生化学検査

Total choresterol, HDL, GOT, GPT, creatinine, BUN, Total protein, albumin, $\mathrm{RBC}, \mathrm{WBC}$, hemoglobin, hematocrit, blood glucose, hydroperoxide, troponinT,TAT ( trombin-antitombin- III ) complex, PT (protrombin) fragment $\mathrm{Fl}+2$, SOD (superoxide dismutase) activityの各項目について競技前後で検査 学行う。

(4) ホルター心電図

ホルター心電図は，競技者の邪魔にならず,しかも外 れないように車椅子にしっかりと固定し，競技中の不整 脈および虚血の出現の有無を観察する。またRR間瀜 変動を時系列 ${ }^{(1)}$ ９) として分析を行う。

\section{3. 解析結果}

\section{1 心拍数と血圧の解析結果}

競技前後における心拍数と血压の変動を表 1 に示す。 競技直後心エコー記録時の心拍数は $99 / \mathrm{min}$ であり 競技前の $66 / \mathrm{min} に$ に比べ有意に増加した。血圧につ いては、収縮期血压は同様に有意に上昇し、拉張期 血圧は有意に低下した。

\section{表1 心拍数と血圧の変動}

Table 1 Change of Heart rate and Blood Pressure

\begin{tabular}{|c|c|c|}
\hline & premarathon & postmarathon \\
\hline Heart rate & $\begin{array}{l}66.0 \pm 12.6 \\
\text { (beats/min) }\end{array}$ & $\begin{array}{l}99.0 \pm 10.8 * \\
\text { (beats } / \mathrm{min} \text { ) }\end{array}$ \\
\hline Systolic blood pressure & $\begin{array}{l}117.7 \pm 18.6 \\
(\mathrm{mmHg})\end{array}$ & $\begin{array}{l}143.0 \pm 12.6 * \\
(\mathrm{mmHg})\end{array}$ \\
\hline Diastolic blood pressure & $\begin{array}{l}70.0 \pm 10.4 \\
(\mathrm{mmHg})\end{array}$ & $\begin{array}{l}45 \pm 8.8 * \\
(\mathrm{mmHg})\end{array}$ \\
\hline
\end{tabular}

mean \pm S.D. $\quad * p<0.05$

\section{$3 \cdot 2$ 心エコ一図による解析結果}

競技前後にお汁る心拍出量と左室収縮期容量、左室 搪張期容量, 駆出率, 未梢血管抵抗, DDR, PEP LVET, 石室径, 左房径の各変動を表2に示す。

心拍出量は上昇傾向を示したが有意ではなく、左室 収縮期容量、左室拡張期容量、駆出率、末梢血管抵 抗、DDR、PEP/LVET、右室径、左房径にも有意な 変化を認めなかった。 
表2 心エコ一図による解析結果

Table2 Echocardiographic results

\begin{tabular}{|l|l|l|}
\hline & premarathon & postmarathon \\
\hline LVESV & $\begin{array}{l}43.2 \pm 12.6 \\
(\mathrm{ml})\end{array}$ & $\begin{array}{l}41.2 \pm 10.3 \\
(\mathrm{ml})\end{array}$ \\
\hline LVEDV & $\begin{array}{l}148.4 \pm 35.2 \\
(\mathrm{ml})\end{array}$ & $\begin{array}{l}150.2 \pm 26.2 \\
(\mathrm{ml})\end{array}$ \\
\hline Ejection fraction & $\begin{array}{l}76.5 \pm 3.6 \\
(\%)\end{array}$ & $\begin{array}{l}77.1 \pm 3.9 \\
(\%)\end{array}$ \\
\hline Cardiac output & $\begin{array}{l}6.4 \pm 1.8 \\
(\mathrm{~L} / \mathrm{min})\end{array}$ & $\begin{array}{l}7.2 \pm 1.4 \\
(\mathrm{~L} / \mathrm{min})\end{array}$ \\
\hline Peripheral vascular & $\begin{array}{l}18.4 \pm 3.1 \\
\text { resistance }\end{array}$ & $\begin{array}{l}19.9 \pm 1.8 \\
(\mathrm{mmH} / \mathrm{gg} / \mathrm{L} / \mathrm{min} / \mathrm{min})\end{array}$ \\
\hline DDR & $\begin{array}{l}112.4 \pm 36.4 \\
(\mathrm{~mm} / \mathrm{sec})\end{array}$ & $\begin{array}{l}114.2 \pm 41.4 \\
(\mathrm{~mm} / \mathrm{sec})\end{array}$ \\
\hline PEP/LVET & $0.29 \pm 0.02$ & $0.31 \pm 0.03$ \\
\hline $\begin{array}{l}\text { Dimeter of right } \\
\text { ventricle }\end{array}$ & $\begin{array}{l}24.8 \pm 4.6 \\
(\mathrm{~mm})\end{array}$ & $\begin{array}{l}25.1 \pm 3.2 \\
(\mathrm{~mm})\end{array}$ \\
\hline Diameter of left atrial & $\begin{array}{l}27.8 \pm 3.6 \\
(\mathrm{~mm})\end{array}$ & $\begin{array}{l}24.9 \pm 4.1 \\
(\mathrm{~mm})\end{array}$ \\
\hline
\end{tabular}

mean \pm S.D.

\section{3 ホルター心電図による解析結果}

ホルター心電図からは，競技中におけるSVPC ( supraventricular premature counter) , V PC (ventricular premature counter)や各種blockおよび有 意なST一T変化は認められなかった。

\section{4 血液生化学による解析結果}

血液生化学分析の結果を表 3 と図 1 〜図5に示す。 TAT complex、WBC は有意な上昇を認めたものの、 他のいずれの項目も競技前後で有意な変化を認めな かった。特に、心筋の虚血性変化の鋭敏な指標として 注目されたTroponin一T についても競技前後でいずれ も 0.1 以下であった。

表3 血液生化学分析結果

Table3 Results of Bood and Biochemical analysis

\begin{tabular}{|l|l|l|}
\hline & premarathon & postmarathon \\
\hline Troponin-T & \multicolumn{1}{|c|}{$\leqq 0.1$} & \multicolumn{1}{c|}{$\leqq 0.1$} \\
\hline TP & $7.3 \pm 0.3(\mathrm{~g} / \mathrm{dl})$ & $7.4 \pm 0.4(\mathrm{~g} / \mathrm{dl})$ \\
\hline lipid peroxide & $\begin{array}{l}4.3 \pm 1.0 \\
(\mathrm{nMol} / \mathrm{ml})\end{array}$ & $\begin{array}{l}3.7 \pm 0.4 \\
(\mathrm{nMol} / \mathrm{ml})\end{array}$ \\
\hline PT fragment & $\begin{array}{l}0.72 \pm 0.20 \\
(\mathrm{nMol} / \mathrm{l})\end{array}$ & $\begin{array}{l}1.1 \pm 0.70 \\
(\mathrm{nMol} / \mathrm{l})\end{array}$ \\
F1+2 & $46.9 \pm 1.0(\%)$ & $46.8 \pm 1.8(\%)$ \\
\hline Hematocrit &
\end{tabular}

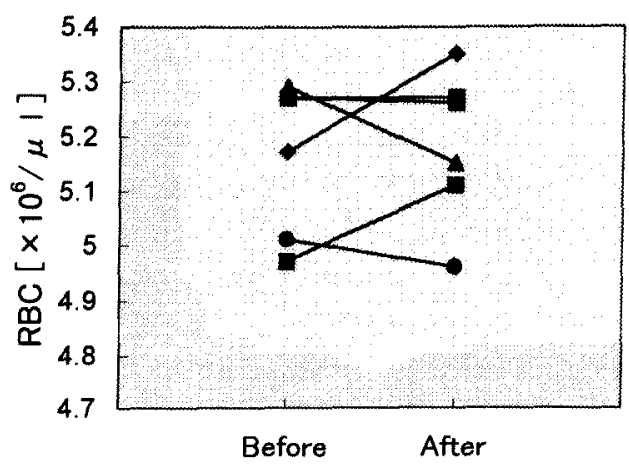

Fig1 Change of RBC

図1 赤血球の変化

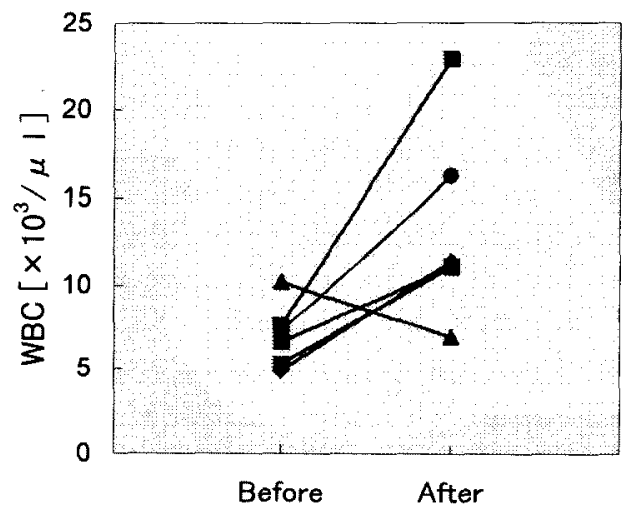

Fig.2 Change of WBC

図2白血球の変化

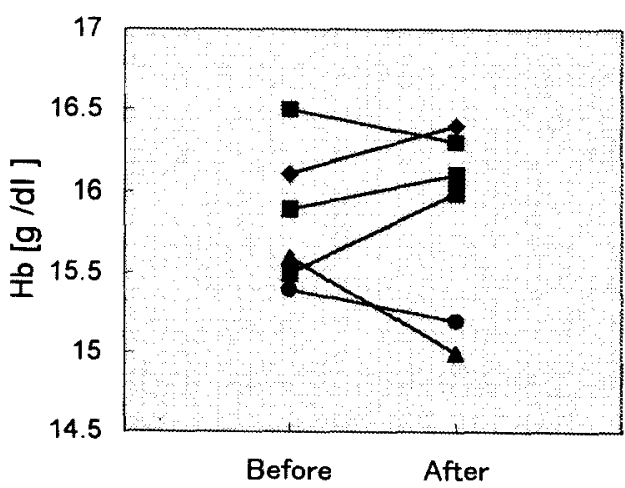

Fig.3 Change of Hemoglobin Value 図3へモグロビンの変化 


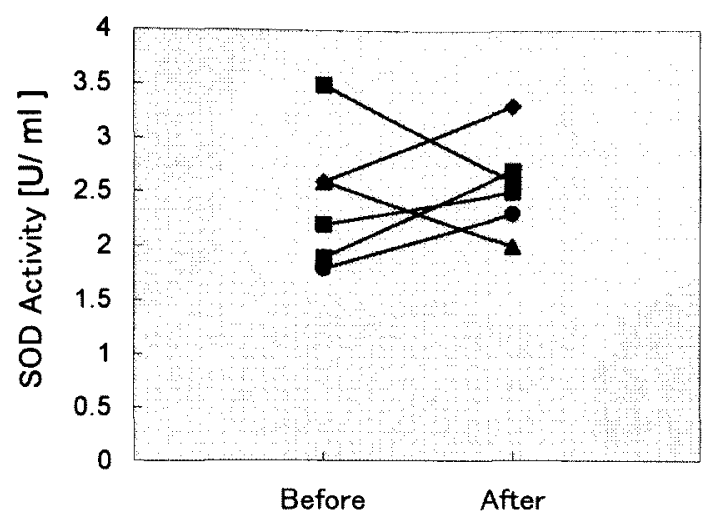

Fig.4 Change of SOD Activity 図4 活性酸素の変化

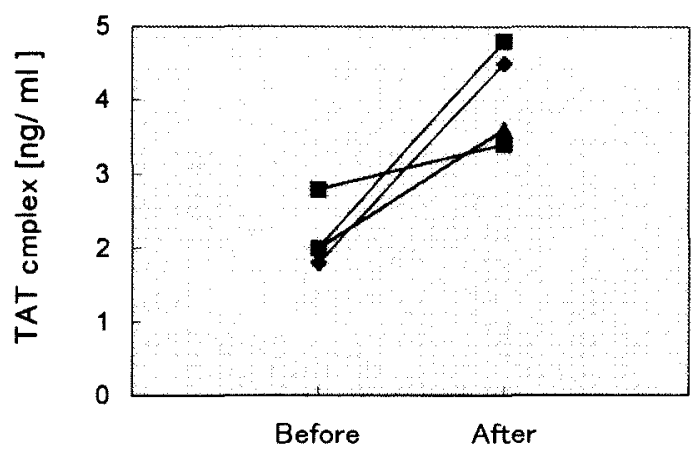

Fig.5 Change of TAT complex 図5 TAT complexの変化

\section{5 RR間隔変動時系列による解析結果}

競技直前, 競技中, 競技直後の心電図RR間隔変 動時系列の周波数分析を図6 図8に示す。心電図の RR間隔変動は自律神経の動向を掴むために用いられ ているが, RR間隔変動時系列を周波数分析することで, 高い周波数成分での検討を行った。マラソンスタート直 前で交感神経優位のため全体的にパワースペクトルが 落ち込んでいるのがわかる5)。マラソン中から直後にか けて高い周波数領域において，優位な落ち込みがす ベての測定者において測定できた。

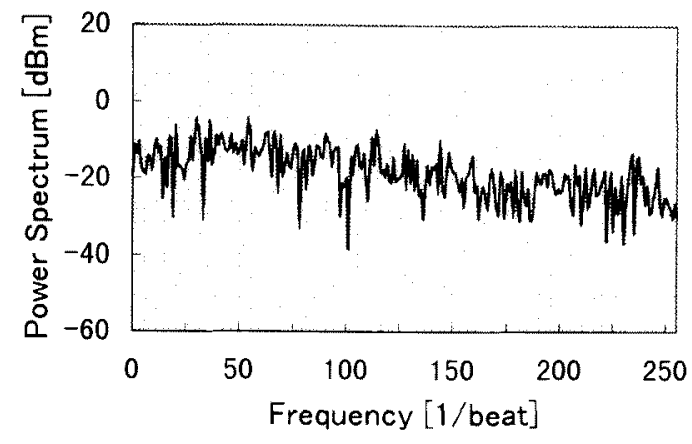

Fig.6 Power Spectrum of $\triangle R R$ interval before the marathon

図6 マラソン直前の $\triangle R R$ 時系列の周波数分析結果

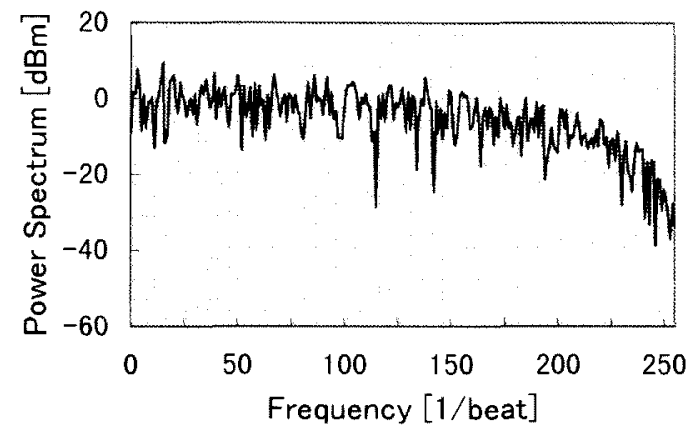

Fig.7 Power Spectrum of $\triangle R R$ interval in the marathon

図7 マラソン中の $\triangle R R$ 時系列の周波数分析結果

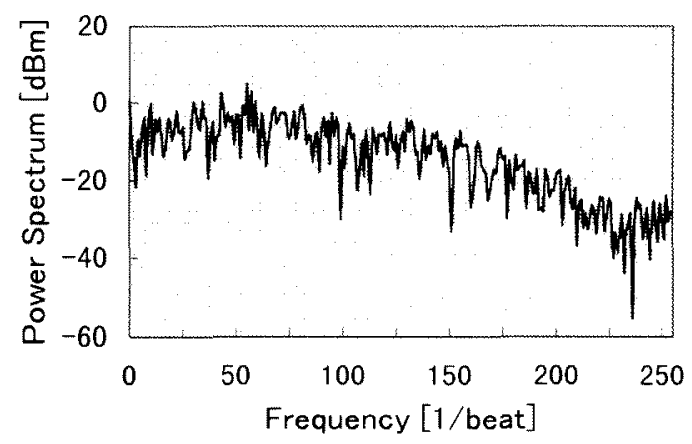

Fig.8 Power Spectrum of $\triangle R R$ interval after the marathon

図8 マラソン直後の $\triangle R R$ 時系列の周波数分析結果

\section{4. 考察}

近年、心断層エコ一法の普及によって、マラソンやトラ イアスロンのような消耗性競技の現場において心機能 
を評価した報告が多く見られるい〜文。

一般に長時間の運動によってもたらされる心機能の 特徵的変化は cardiovascular drift といわれ、心拍数 は増加するにも関わらず一回拍出量が低下するため心 拍出量の增加はみられない。その機序は循環血液量 低下や一過性の心収縮自体の低下 (cardiac fatigue) などであろうといわれている。Douglas らは、ハワイトライ アスロン参加者を対象に、競技前後で心エコ一図を用 いて心機能の変化を検討し、一過性ではあるが内径短 縮率の低下や stress-shortening 関係より cardiac fatigue が起こっていることを報告している゙”。収縮性 の変化が代謝性の因子によるものか、あるいは心䈘自 体の障害によるものか、その原因は明らかではない。ま た左室機能の低下が左右心室の直接的相互関与によ って起こる可能性を示唆した論文も報告されている゙”。 しかし、血液凝固能老鋭敏に検出する TAT complex の有意な上昇を認めたことから、今回の対象者の上うな 30 歳代では余りその可能性は少ないと思われる。また、 過酸化脂質 (hydroperoxide)、SOD activity に有意な 変化を認めなかったことおよび Troponin-T の增加も 認めなかったことにより、虚血・再潅流障害は特に心筋 に出現していないことが示唆された。

また、白血球の増加はストレスによるものと考えられた。 本研究の結果加ら、少なくとも 30 歳代と比較的若年 の身体障害者で、動脈硬化もほとんどないであろう参 加者は、日頃から十分に訓練をした上で競技にのぞみ、 競技中も十分な水分補給をしていれば、心機能への影 響はなく、安全に競技を行うことが可能であるといえる。

またホルター心電図からRR間隔時系列の変動を周波 数分析で行ったが，上肢だけの激しい運動のためかな り基線のずれが発生し，そのアーチファクトのた必要 な情報が正確には抽出できずに細部にわたる検討が できなかった 後で同じ傾向を示していた。

今後は選手の高齡化もあり、これらのひとでは十分な メディカルチェックを行う必要がでてくるものと考えられ 死。

\section{5. 結論}

車椅子マラソンの運動負荷後における心機能への影 響を生理学的および生化学的に評価を行った。次のよ うな結果を得られた。

（1）心エコ一図上有意な変化は認められず、トライア スロン競技でみられた左室収縮力の低下は全く 認めなかった。また、血液生化学検査の結果か らも心筋の損傷を示唆する所見は認められなか 施。

（2）血液生化学検査の結果からは、まず一番心配さ れた脱水所見は認められなかった。
（3）高齢の動脈硬化の存在が心配される人には、よ り綮重な梗塞性疾患の予防が、競技中の十分な 水分掑取などを始め必要になることが示唆され t。

上肢だけで過激な運動を行う経験のない健常者か らみればかなりの心臟への負荷がかかりそうに思えるが， 今回の被験者は，普段から日常生活がすべて車椅子 であること, 毎日十キロ以上の距離を走ってトレーニン グをしているため, 十分心機能が代償されているという 結果が得られた。こように30歳代と比較的若年の身 体障害者で、動脈硬化もほとんどないであろう参加者 は、日頃から十分に訓練をした上で競技にのぞみ、競 技中も十分な水分補給をしていれば、心機能一の影響 はなく、安全に競技を行うことが可能であるといえる。

今後は，車椅子での生活を普段行っているが，車椅 子マラソンに備えて十分なトレーニング等は特別に行っ ていない参加者や高年龄者についての検討を行って いく予定である。

(平成8年10月29日受付)

\section{文献}

1) Douglas, P.S. et al.: Cardiac fatigue after prolonged exercise.

Circulation 76 :1206-1213, 1987.

2) Niemela K.O., Palatsi L.J. et al. : Evidence of impaired left ventricular performance after an uninterrupted competitive 24 hour run. Circulation $70: 350-356,1984$.

3) Douglas P.S., O'Toole M.L., et al. : Different effects of prolonged exercise on the right and left ventricle. J Am Coll Cardiol 15 :64-69, 1990.

4) Perraut H., Peronnet F., et al. :Echocardiographic assessment of left ventricular performance before and after marathone running. Am Heart J 112 : 1026-1031, 1986.

5) N.S. Cherniack, et al.: Respiratory control during sleep, 37th ACEMB, 326, 1984

6)佐藤昭夫 他:医科生理学展望, 丸善, 192, 1985

7) J.R.Smith, et al.: Detection of the human sleep and EEG waveform, EEG Neurophysiol., 38, 435437,1975

8) T.Nishimura: Method and apparatus for correlating respiration and heartbeat variability, United States Patent 5105354

9) T.Nishimura: A method of forecast for the reduction of risk factors on sudden infant death syndrome, JIEICE, Med.\& bio Cybernet. 88, MBE88-25, 29-34, 1988 


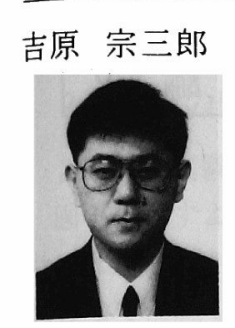

(正員)1962年12月 23 日生。1987年 3 月大分大学大学院工学研究科修士 課程修了。1992年4月大分県教育セ ンター情報教育部勤務, 現在に至る。 医用生体工学, 自律神経系のモデル, 超音波信号の解析の研究に従事。日 本超音波医学会, 日本ME学会会員。

西村 敏博

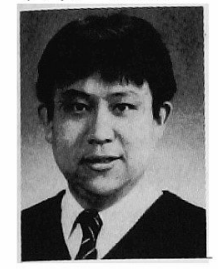

(正員)1950年4月9日生。1978年大分 大学工学部電気工学科卒業。同年同 大学工学部電気工学科助手, 現在に 至る。工学博士。医用生体工学, 特に 循環器系のモデル化, 超音波診断装 置, 完全埋込型人工心臓システム, 心臟ペースメーカ, 人工臟器のエネ ルギー転送システム, 半導体電力変

換工学などの研究教育に従事。電気学会医用生体工 学技術委員会幹事。電子情報通信学会, 日本ME学 会, 日本超音波医学会, LST学会, IEEE会員。

細川 博司

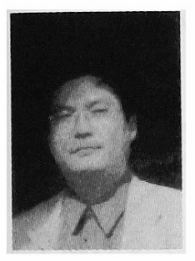

(非会員) 1986年大分医科大学医学 部医学科卒業。1993年同大学院博士 課程修了。1994年大分医科大学公衆 衛生医学講座第一医学部助手。1996 年医療法人渡辺会渡辺クリニック院 長, 現在に至る。医学博士。冠動脈造 影及び形成術, 心および腹部エコー, 消化器内視鏡術, 循環器科内科, 消

化器内科, 心療内科の各臨床, 新薬治験, 薬効評価 の研究に従事。日本内科学会, 日本臨床薬理学会, 日本薬理学会, 日本循環器学会会員。

濱本 和彦

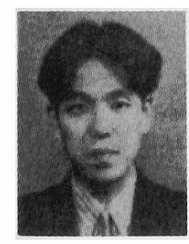

(正員) 1994年東京農工大学大学院博 士後期課程修了。同年東海大学工学 部助手, 1995年同講師。博士(工学)。 医用電子工学の分野において, 超音 波を用いた生体加温・画像処理およ び信号処理, 医療情報通信に関する 研究に従事。日本ME学会専門別研 究会幹事。IEEE, 日本ME学会, 日

本超音波医学会, 電子情報通信学会, 日本医用画像 工学会, 他会員。1995年度電気学会優秀論文発表賞 受賞。

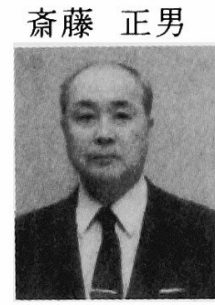

(正員)1956年東京大学工学部卒業。 1962年同大学大学院博士課程修了。 同大学工学部講師, 助教授を経て, 1974年同医学部教授。同大学退官後, 東京電機大学教授。工学博士。回路 システム理論, 医用生体工学の研究 教育に従事。日本ME学会会長, 日本 ハイパーサーミア学会副会長, LST学 会会長, 国際ME学会会長, 日本学術会議医用生体 工学研連委員長を歴任。電子情報通信学会稲田賞, 論文賞, 日本ME学会論文賞受賞。国際ME学会名誉 会員。 